\title{
A METHOD FOR REFORMING THE PATENT SYSTEM $\dagger$
}

\author{
Peter S. Menell*
}

\author{
Cite as: Peter S. Menell, A Method for Reforming the Patent System \\ 13 Mich. Telecomm. Tech. L. Rev. 487 (2007), \\ available at $\mathrm{http}: / / \mathrm{www} . \mathrm{mttl}$.org/volthirteen/menell.pdf
}

\begin{abstract}
The principal recent studies of patent reform (NAS (2004), FTC (2003), Jaffe and Lerner (2004)) contend that a uniform system of patent protection must (or should) be available for "anything under the sun made by man" based upon one or more of the following premises: (1) the Patent Act requires this breadth and uniformity of treatment; (2) "discriminating" against any particular field of "technology" would be undesirable; (3) discrimination among technologies would present insurmountable boundary problems and could easily be circumvented through clever patent drafting; and (4) interest group politics stand in the way of excluding any subject matter classes from patent law or reforming the patentability requirements, duration, defenses, or remedies for a particular subject matter class. As a result, these studies consider and recommend reforms that would apply to all fields of patentable subject matter ("systemic reforms") and largely ignore reforms that would either bar particular classes of "technology" from patent protection (e.g., software, business method, genomic sequences) or afford different classes of patentable subject matter different requirements or remedies ("categorical reforms"). This Article sets forth a method for evaluating and formulating patent policy that considers both systemic and categorical reforms and sketches out how that method could be applied to the current patent "crisis."

$\dagger \quad$ This Article is fashioned as a patent application to illustrate the patent system's shift away from subject matter limitations and highlight the need for a neutral, comprehensive framework for patent system reform. To the extent that the style of this Article creates any misimpression about its purpose, any ideas contained herein are dedicated to the public.

Professor of Law and Director, Berkeley Center for Law \& Technology, University of California at Berkeley School of Law (Boalt Hall). I thank Brian Kahin for organizing the conference on Patents and Diversity in Innovation held at the University of Michigan Law School on September 29-30, 2006, Robert Barr for valuable and enjoyable conversations about patent reform, Jonathan Band, Bob Hunt, Mark Lemley, and Lee Van Pelt for comments on an earlier draft, and Tom Fletcher for research assistance. I bear full responsibility for the views and shortcomings of this Article.
\end{abstract}




\section{Background}

\section{Technical Field}

Prior to 1998 , it would have been difficult, if not impossible, to assert that this Article fit within any field of patentable subject matter. But under the Federal Circuit's expansive interpretation of patentable subject matter-essentially collapsing the subject matter inquiry into the utility requirement - - conomists, lawyers, television production executives, script writers, and just about anyone else can now characterize their creativity as falling within a technical field. ${ }^{2}$ Under this expansive conception, the claimed "invention" described and claimed herein fits generally within the "technical" field of patent policy analysis. Ironically, the "invention"-if implemented properly-would likely block the very type of protection sought herein. But as suggested in Claim 2, the "invention" is most likely to be politically feasible only if applied prospectively.

\section{Background of the "Invention"}

The proper contours of patent protection have long been complex and controversial. The optimal threshold, duration, and scope of even a one-shot invention (i.e., an invention which does not serve as a building block for later inventions) requires balancing the incentives to invent against the dead weight loss from monopoly exploitation. There is good reason to believe that this balance will vary across technological fields. When cumulative innovation is introduced into the equation, the optimal level of protection becomes even more complex as the standards for protection, duration, and scope must appropriately balance between pioneering inventors and those who build upon their inventions. The patent system also discloses knowledge that can be valuable in promoting cumulative innovation. The policy calculus is further complicated by the range of other motivations for and means by which inventors and inves-

1. See AT\&T Corp. v. Excel Commc'ns, Inc., 172 F.3d 1352 (Fed. Cir. 1999), cert. denied, 528 U.S. 946 (1999); State Street Bank \& Trust Co. v. Signature Fin. Group, Inc., 149 F.3d 1368 (Fed. Cir. 1998), cert. denied, 525 U.S. 1093 (1999).

2. See Floyd Norris, You Can't Use That Tax Idea. It's Patented, N.Y.TImes, Oct. 20, 2006, at $\mathrm{Cl}$ (reporting that the U.S. Patent and Trademark Office has issued 49 patents on tax avoidance strategies); Andrew F. Knight, A Patently Novel Plot: Fiction, Information, and Patents in the 21st Century, 47 IDEA 203 (2006); Gregory Aharonian \& Richard Stim, Patenting Art \& Entertainment: New Strategies for Protecting Creative Ideas (2004). 
tors can derive a sufficient expected rate of return to stimulate their inventive efforts. For example, public funding of research, lead time advantages, the availability of other forms of legal protection for creativity (trade secrecy; copyright protection for computer software), reputational benefits (protected through trademarks), ancillary means of deriving revenue from investments in creativity and inventions (such as bundled advertising), and technological protection measures (such as digital rights management) can substitute for and complement patent protection. The policy calculus also considers direct and indirect costs of patent protection-administration of the patent system, the direct costs of prosecuting patent applications, the indirect costs of pursuing patents (e.g., distractions and paperwork burdens for inventors), the costs of maintaining and enforcing patents, and the due diligence burden imposed upon inventors and investors to avoid patent infringement. Finally, the patent system can facilitate and perpetuate anti-competitive business practices (collusion and market exclusion).

Given the heterogeneity of inventive resources and opportunities, no one-size-fits-all system of protection can achieve "first best" optimality. A uniform patent system that applies to all fields of technology will undoubtedly be both under and over-inclusive. On the other hand, administrative and political constraints caution against significant discretion in the granting and tailoring of patent protection. Thus, the efficacy of the patent system depends on the extent to which rules of general applicability can distinguish among varying circumstances. The nonobviousness requirement, for example, calibrates the appropriate benchmark for patentability within fields of invention based on the "person having ordinary skill in the art" (PHOSITA). ${ }^{3}$ Yet, such a standard is limited in its ability to control for all of the factors relevant to the optimal level of protection. Several important variables-such as the duration of the protection, infringement standards, defenses, and remedies-are largely fixed and constant across technological fields. ${ }^{4}$ Furthermore, the patent system overlooks several critical variables, including the cost of innovation; the extent to which other means of

3. See Dan L. Burk \& Mark A. Lemley, Is Patent Law Technology Specific?, 17 BerKeley TeCh. L.J. 1155 (2002).

4. The patent system provides for some technology-specific variation. See, e.g., 35 U.S.C. $\$ 287$ (c) (1999) (barring enforcement of medical procedure patents against medical practitioners or related health care entities); 35 U.S.C. $\$ 273$ (1999) (providing a limited prior user right with regard to business method patents). Section 155 allows for the term of drug patents to be extended to compensate for regulatory review by the Food and Drug Administration, although this provision can be seen as preserving a uniform duration of effective protection, not optimizing protection based on the costs and difficulty of invention. 
recouping investment exist; or technology-specific economic effects (e.g., network effects). ${ }^{5}$

Many prior art patent policy assessments proceed under the assumption that patent law must be essentially "technology neutral": that it must extend to all "technologies," that it must apply the same general standards to protectability, and that it must afford all technologies the same rights and remedies. ${ }^{6}$ Nonetheless, until recently judicial interpretation of both the constitutional authority under which Congress may enact patent protection and the Patent Act itself constrained the subject matter of patent protection along several dimensions.' The Federal Circuit, however, has largely removed such constraints through narrow interpretation of Supreme Court precedent and questionable interpretation of the Patent Act of $1952 .^{8}$

Several scholars have questioned the patentability of some classes of technology on both jurisprudential and public policy grounds. ' Some of

5. See Peter S. Menell, Tailoring Legal Protection for Computer Software, 39 STAN. L. REv. 1329 (1987).

6. A notable exception is Dan L. Burk \& Mark A. Lemley, Policy Levers in Patent Law, 89 VA. L. REV. 1575 (2003), which proposes various technology-specific adjustments.

7. See Diamond v. Diehr, 450 U.S. 175, 185 (1981) ("This Court has undoubtedly recognized limits to $\S 101$ and every discovery is not embraced within the statutory terms. Excluded from such patent protection are laws of nature, natural phenomena, and abstract ideas."); Parker v. Flook, 437 U.S. 584 (1978); Gottschalk v. Benson, 409 U.S. 63 , 67 (1972) ("'[p]henomena of nature, though just discovered, mental processes, and abstract intellectual concepts are ... the basic tools of scientific and technological work"); Funk Bros. Seed Co. v. Kalo Inoculant Co., 333 U.S. 127, 130 (1948) (fundamental scientific principles as "part of the storehouse of knowledge" and manifestations of laws of nature as "free to all men and reserved exclusively to none"); Mackay Radio \& Tel. Co. v. Radio Corp. of Am., 306 U.S. 86, 94 (1939) ("a scientific truth, or the mathematical expression of it, is not patentable invention"); O’Reilly v. Morse, 15 How. 62, 14 L.Ed. 601 (1854); see also Kewanee Oil Co. v. Bicron Corp., 416 U.S. 470, 483 (1974) ("Since no patent is available for a discovery, however useful, novel, and nonobvious, unless it falls within one of the express categories of patentable subject matter of 35 U.S.C. $\S 101$, the holder of such a discovery would have no reason to apply for a patent whether trade secret protection existed or not. Abolition of trade secret protection would, therefore, not result in increased disclosure to the public of discoveries in the area of nonpatentable subject matier. Also, it is hard to see how the public would be benefited by disclosure of customer lists or advertising campaigns; in fact, keeping such items secret encourages businesses to initiate new and individualized plans of operation, and constructive competition results. This, in turn, leads to a greater variety of business methods than would otherwise be the case if privately developed marketing and other data were passed illicitly among firms involved in the same enterprise.").

8. See AT\&T Corp. v. Excel Commc'ns, Inc., 172 F.3d 1352 (Fed. Cir. 1999); State Street Bank \& Trust Co. v. Signature Fin. Group, Inc., 149 F.3d 1368 (Fed. Cir. 1998).

9. See Linda J. Demaine \& Aaron Xavier Fellmeth, Reinventing the Double Helix: A Novel and Nonobvious Reconceptualization of the Biotechnology Patent, 55 STAN. L. REv. 303 (2002); Pamela Samuelson, Benson Revisited: The Case Against Patent Protection for Algorithms and Other Computer Program-Related Inventions, 39 EмоRу L.J. 1025 (1990); Peter S. Menell, Tailoring Legal Protection for Computer Software, 39 STAN. L. REv. 1329 (1987). 
these studies have proposed alternative regimes for protecting these works. To the extent that others have suggested excluding some classes of "technology" from the patent system, these analyses have not fully compared the advantages and disadvantages of the full range of policy alternatives. This invention asserts that the answer to the question "should we pursue systemic or categorical patent reform?" is not one or the other but both and offers a comprehensive framework for structuring this inquiry.

\section{Summary of the "Invention"}

The method described herein provides a comprehensive framework for formulating and evaluating patent policy. It recognizes that systemic reform proposals are limited in their ability to address the full range of variability affecting the optimal encouragement of technological innovation through patent protection, and that categorical reform proposals overlook interactive effects with systems reforms. Therefore, it recommends a parallel track process for considering both sets of reforms as well as integrated policy reforms. Finally, it assesses the administrative and political feasibility of pursuing such reforms.

\section{Description}

\section{The Economics of Intellectual Property Protection for Functional Works ${ }^{10}$}

The principal justification for intellectual property derives from a broader economic problem: the inability of a competitive market to support an efficient level of innovation in some areas of technology, particularly those areas in which research and development (R\&D) is costly, innovation is easily perceived, and imitation is relatively inexpensive and can occur rapidly. In a competitive economy, profits will be driven to zero, not accounting for sunk costs such as R\&D. Although imitation keeps prices low for consumers and avoids the deadweight loss of monopolistic pricing, it produces a sub-optimal level of investment in R\&D. Most firms would not invest in developing new technologies if rivals could enter the market and dissipate the profits before $R \& D$ costs,

10. This section draws upon Peter S. Menell \& Suzanne Scotchmer, Intellectual Property Law, in HANDBoOK of Law and Economics (A. Mitchell Polinsky \& Steven Shavell eds., forthcoming 2007); Peter S. Menell, Intellectual Property: General Theories, in 2 ENCYClOPEDIA OF LAW AND ECONOMICS (Boudewijn Bouckaert \& Gerrit de Geest eds., 2000). 
adjusted for attendant risks, could be recovered. Economists refer to this phenomenon as an appropriability problem. Prospective inventors will underinvest in R\&D if they are unable to derive an adequate rate of return on their investment.

Unlike tangible goods, knowledge and creative works are public goods in the sense that their use is nonrivalrous. One agent's use does not limit another agent's use. Indeed, in its natural state, knowledge is also "nonexcludable." That is, even if someone claims to own the knowledge, it is difficult to exclude others from using it. Intellectual property law is an attempt to solve that appropriability problem by legal means; it grants exclusive use of the protected knowledge or creative work to the inventor or creator. For other forms of property, exclusion is often accomplished by physical means, such as building a fence. (In some contexts, inventors can prevent or hinder access to technology through encryption or other means of limiting access to knowledge. Such approaches can work for some process inventions, but are not available with regard to products that can be understood by inspection or disassembly.) Intellectual property is a legal device by which the inventor can control entry and exclude users from intangible assets.

Such control, however, reduces social welfare in several ways. First, monopoly pricing results in deadweight loss to consumers. Two other defects are that it may inhibit the use of scientific or technological knowledge for further research, and, from an ex ante point of view, there is no guarantee that the research effort will be delegated efficiently to either the most efficient firms or to the right number of firms. Commentators have lamented the defects of intellectual property since the nineteenth century, in more or less the same terms as today."

Patent protection seeks to balance these competing effects by affording protection only to substantial (non-obvious) inventions, limiting the term of protection, and requiring that the inventor fully disclose the invention. In the most basic model of patent protection-where inventions do not serve as building blocks for later inventions and the only control variable is the duration of protection-Nordhaus showed that the optimal duration of patent protection balanced the incentives for innovation against the deadweight loss of monopoly exploitation. ${ }^{12}$

Cumulative innovation-where first generation inventions become inputs for second generation innovators-substantially complicates the design of patent protection. In order to reward first generation innovators

11. See Fritz Machlup \& Edith Penrose, The Patent Controversy in the Nineteenth Century, 10 J. Econ. Hist. 1 (1950).

12. See generally William D. Nordhaus, Invention, Growth and Welfare; A Theoretical Treatment of Technological Change (1969). 
sufficiently for inventions that may produce positive spillovers by enabling second generation inventions (improvements, new applications, and accessories), first generation innovators should be able to appropriate some of the value of second generation innovations. ${ }^{13}$ On the other hand, providing even a share of the second generation innovators' returns to the first generation innovator reduces the incentive for second generation innovators to pursue their research. This tension is abated to the extent that first generation innovators are best positioned to pursue second generation innovation or where collaboration (e.g., joint ventures) brings the first and second generation innovations within the same profit center. ${ }^{14}$ The cumulative nature of innovation unquestionably strengthens the case for allowing joint ventures, especially with respect to complementary products. ${ }^{15}$ In practice, however, it is rare that one entity is best positioned to pursue all second generation projects. Furthermore, second generation innovators are not known (and cannot be knowable) before first generation research investments must be made. Yet, once first generation research investments are made, they are sunk costs which become irrelevant for bargaining over the division of profits from multi-generation innovation. This problem can be addressed by expanding the duration and scope of first generation patents or by denying patent protection altogether to second generation innovation. ${ }^{16}$ These results, however, depend critically upon strong assumptions relating to licensing of innovation and the knowledge and rationality of innovators. As the institutional literature notes, there are many strategic impediments to licensing of innovation. ${ }^{17}$ In addition, much of the institutional literature casts doubt on the degree to which innovators possess good information for assessing the best diffusion path for their technologies and whether innovators behave rationally in licensing to actual and potential competitors. ${ }^{18}$

Figure 1 illustrates the range of factors affecting the optimal design for patent protection and indicates the conditions favoring strong

13. See Suzanne Scotchmer, Standing on the Shoulders of Giants: Cumulative Research and the Patent Law, 5 J. ECON. PERSP. 29 (1991).

14. See Edmund W. Kitch, The Nature and Function of the Patent System, 20 J.L. \& ECON. 265 (1977).

15. See Suzanne Scotchmer, Patents as an Incentive System, 2 Econ. In a Changing World 281 (Beth Allen ed., 1996); See also Michael L. Katz \& Janusz A. Ordover, $R \& D$ Cooperation and Competition, 1990 Brookings PAPERS on ECON. ACTIVITY: MicroecoNOMICS 137.

16. See Jerry R. Green \& Suzanne Scotchmer, On the Division of Profit in Sequential Innovation, 26 RAND J. ECON. 20 (1995).

17. See Robert P. Merges \& Richard R. Nelson, On the Complex Economics of Patent Scope, 90 Colum. L. Rev. 839 (1990).

18. See Mark A. Lemley, The Economics of Improvement in Intellectual Property Law, 75 TEX. L. REv. 989 (1997). 
protection on the one hand, and weak or no protection on the other. The most important considerations in assessing the need for patent protection are the cost of research and development (especially in relation to imitation costs), the technological risk associated with such research, and the availability of effective non-patent means of protection. The pharmaceutical industry has long been recognized as depending critically upon patent protection due to the high costs of research, the great uncertainty in the discovery process, and the ease of imitation of the final product. Trade secret protection can afford some protection for process inventions, but relatively less for products. By contrast, the costs of much software innovation today is relatively low. Powerful computers can be obtained for a modest investment and the versatility of computing machines and programming languages provide a relatively high likelihood of success for many software development projects. Furthermore, the availability of alternative means of protecting innovation-including direct public funding of innovation, other means of legal protection (copyright, trade secrecy, trademark), technical means of protection (for example, metered access through the use of encryption), and market-based protections (lead-time/first mover advantage, ancillary means of appropriating a return to an invention (such as bundling access to a product or service with advertising), general reputational benefits)-can substitute for and in some cases obviate the need for patent protection. Software, for example, can be protected against piracy by copyright and against functional imitation by trade secrecy, technological protection measures, and contractual restraints. On the other hand, patent protection may counteract the adverse effects of trade secrecy protection by promoting disclosure of knowledge. ${ }^{19}$ But in the case of software, this benefit has largely been compromised by court decisions allowing software to be claimed in highly abstract ways without the need to disclose source code. ${ }^{20}$

19. See David D. Friedman, William M. Landes, \& Richard A. Posner, Some Economics of Trade Secret Law, 5 J. Econ. PersP. 61 (1991).

20. Fonar Corp. v. General Electric Co., 107 F.3d 1543 (Fed. Cir. 1997). 
Figure 1

Economic Criteria for Assessing Patent Protection

\begin{tabular}{|c|c|c|}
\hline $\begin{array}{c}\text { Strongest Conditions for } \\
\text { Patent Protection }\end{array}$ & R\&D & $\begin{array}{c}\text { Conditions Disfavoring } \\
\text { Patent Protection }\end{array}$ \\
\hline High & Technological Risk & Low \\
\hline High & Public Funding & High \\
\hline Low & $\begin{array}{c}\text { Availability of Alternate } \\
\text { Appropriability Mechanisms }\end{array}$ & Effective \\
\hline Ineffective & $\begin{array}{c}\text { Importance/Nalue of Patent } \\
\text { Disclosure }\end{array}$ & Insubstantial \\
\hline Substantial & $\begin{array}{c}\text { Cumulativeness of } \\
\text { Innovation/Effectiveness of } \\
\text { Licensing Institutions }\end{array}$ & $\begin{array}{c}\text { Narrower scope if highly } \\
\text { cumulative and high } \\
\text { licensing costs }\end{array}$ \\
\hline $\begin{array}{c}\text { Broader scope if not highly } \\
\text { cumulative and/or low } \\
\text { licensing costs }\end{array}$ & Network Effects & $\begin{array}{c}\text { Substantial and costly } \\
\text { standard }\end{array}$ \\
\hline $\begin{array}{c}\text { None or effective standard } \\
\text { setting }\end{array}$ & Clarity of Rights/Due \\
\hline Clear boundaries & Fuzzy boundaries \\
\hline Low & Leveraging/Misuse Potential & High \\
\hline Low & Other Abuse Problems & High \\
\hline
\end{tabular}

From an economic standpoint, therefore, the case for patent protection for particular types of inventions will vary. Due to the heterogeneity of inventive activity, the relatively uniform features of patent protection inevitably leads to under- and over-protection for particular technologies. Patent protection initially arose in the age of mechanical inventions. The system adapted reasonably well to later technological waves, from chemical to electrical to pharmaceutical innovation. But even in these fields, the need for, and efficacy of, the patent protection varied. ${ }^{21}$ Each of these areas tended to fit the prototypical scenario for which patent law was designed: the need to ensure that investors and inventors could appropriate an adequate return for their investments in $R \& D$. The advent of computer software and genomic research introduced several distinctive ingredients into the patent policy equation, including substantial government funding of research, highly cumulative characteristics, network effects (in the case of software), and a wide range of ancillary means of protecting innovation (software).

21. See Richard C. Levin et al., Appropriating the Returns from Industrial $R \& D, 3$ Brookings PAPERS on ECON. Activity 783 (1987). 


\section{Fallacies of the "One-Size-Fits-All Patent" Reform Paradigm}

Notwithstanding the heterogeneity of inventive activity and the technology-specific variability among the factors affecting the efficacy of the patent system, the leading patent reform studies adopt a "one-size-fits-all" paradigm and largely disregard subject matter exclusions or technology-specific rules.

Perhaps the most surprising study to dismiss categorical reforms is Innovation and Its Discontents: How Our Broken Patent System Is Endangering Innovation and Progress, and What to Do About It, a monograph by Professors Adam Jaffe and Josh Lerner, two leading empirical economists who have studied several aspects of the patent system. ${ }^{22}$ Their book attributes the crisis in U.S. patent law to two largely administrative developments over the past two and a half decades: (1) the creation of a specialized patent appellate court (the Court of Appeals for the Federal Circuit), which has significantly and unjustifiably broadened patent holder's rights; and (2) a shift in funding at the Patent Office in the early 1990s that has severely undercut the quality of patent examination. As remedies, they recommend expanded opportunities for interested third parties to participate in the patent examination and review process (most notably, the development of an effective opposition system along the lines of that used in Europe) and better funding of the Patent Office.

Given their comprehensive discussion of the economics of patent policy, ${ }^{23}$ it is remarkable that they so readily reject categorical reform choices. Their position is based less on a careful analysis of the costs and benefits of such policy options and more on a variety of cursory objections. Although they include the expansion of patentable subject matter among the causes for the overbroadening of patent protection, ${ }^{24}$ they seem resigned to the view that patent law must extend to "anything under the sun that is made by man." 25 They confront this issue more directly

22. Adam B. JafFe \& Josh Lerner, InNovation and Its Discontents: How OUR Broken Patent System Is Endangering Innovation and Progress, and What to Do ABOUT IT (2004).

23. Id. at 25-77.

24. Id. at $115-19$.

25. Diamond v. Diehr, 447 U.S. 303, 309 (1981). Jaffe and Lemer note that the phrase originated in the legislative report accompanying the 1952 Patent Act. See Jaffe \& Lerner, supra note 22 , at $216 \mathrm{n}$. 92 . They fail to appreciate, however, that this quotation was used out of context and a full reading of the legislative history indicates that Congress did not intend to expand patentable subject matter through the 1952 Act beyond recognizing use patents. Congress fully intended to retain the doctrines limiting patentable subject matter. See generally Peter S. Menell, Are Software Patents "... anything under the sun made by man ..."? (manuscript in progress 2007, on file with author); Brief for Computer \& Communications Industry Association as Amici Curiae Supporting Petitioners at 4-10, Laboratory Corp. of 
in their recommendations chapter. Although recognizing that "the major problems" in the patent system are perceived to be in the areas of "software, business methods, and certain aspects of biotechnology such as genetic sequences," they assert without further explanation that these problems are merely transitional ${ }^{26}$ and "manifestations of the broader problems of the system as a whole." ${ }^{27}$ They worry that technology-specific reforms would open up the patent system to a Pandora's box of special pleading. ${ }^{28}$

In rejecting exclusion of business methods, Jaffe and Lerner resort to an ad hominem argument, suggesting that opposition to business method patents is a form of "techno-snobbery."29 They then argue by analogy to other areas of patentable subject matter (that might or might not merit patent protection):

As a general proposition, important new business methods are not dissimilar from other forms of innovation: they often require major investments of time and money in development; there are methods other than patents (e.g., secrecy) that can sometimes be used to protect these investments, but there are also cases where, in the absence of patent protection, the risk of imitation would seriously undermine development incentives. ${ }^{30}$

Yet Jaffe and Lerner provide no concrete evidence to suggest that appropriability is now lacking in the development of business method patents (which were outside of patent protection for the first two centuries of U.S. patent law and remain so in Europe and Japan) or that the benefits of patent protection outweigh the anticompetitive harms and other mischief caused by allowing such patents. ${ }^{31}$ Instead, they presume that all "inventions" should be entitled to patent protection and assert that the success of their proposed patent system reforms in weeding out bad patents means that categorical adjustments need not be considered at all.

America Holdings v. Metabolite Laboratories, Inc., No. 04-607 (U.S. June 22, 2006), 2006 U.S. LEXIS 4893. In any case, economic analysis should be guided not by legal interpretation but by social welfare. Congress can certainly revise the contours of patentable subject matter.

26. Jaffe \& Lerner, supra note 22 , at $145-48$.

27. Id. at 198.

28. Id.

29. Id. at 199.

30. Id. at 200.

31. See Rochelle Cooper Dreyfuss, Are Business Method Patents Bad for Business?, 16 Santa Clara Computer \& High Tech. L. J. 263 (2000); See also Michael J. Meurer, Business Methods and Patent Floods, 8 WASH. U. J.L. \& PoL'y 309 (2002); See also Michael J. Meurer, Controlling Opportunistic and Anti-competitive Intellectual Property Litigation, 44 B.C. L. Rev. 509 (2003); cf. John R. Thomas, The Patenting of the Liberal Professions, 40 B.C. L. REv. 1139 (1999). 
Along similar lines, Jaffe and Lerner discount assertions that the cumulative nature of software innovation might justify categorical treatment because most fields of technology advance cumulatively. ${ }^{32}$ This response, however, oversimplifies the economic significance of field-specific differences. They note earlier in their book that the nature and effectiveness of cross-licensing plays a critical role in assessing the efficacy of the patent system, ${ }^{33}$ yet they make no effort to apply this insight in considering reforms. Furthermore, by addressing but a few of the factors in the patent protection matrix (Figure 1), Jaffe and Lerner marginalize categorical reform options. But the magnitude of the U.S. patent system's failings in particular technological fields, the "rational ignorance" of the Patent Office, ${ }^{34}$ and the costs of achieving an optimal balance of false positives (patents that should not issue) and false negatives (improper rejections) ${ }^{35}$ could justify patentable subject matter exclusions. Furthermore, the particular characteristics of business methods, software, or genomic code may justify promulgation of rules specific to these fields of "invention."

The National Academies of Science 2004 report, A Patent System for the 21 st Century, ${ }^{36}$ also gives short shrift to categorical patent law reforms. While drawing on a collection of industry-specific studies detailing substantial inter-industry differences bearing on optimal patent protection, ${ }^{37}$ the National Academy of Sciences ("NAS") Report side-steps consideration of categorical reforms by adopting as its first evaluation criterion the principle that "the patent system should accommodate new technologies." "It interprets this criterion to mean that the patent system should be "unitary" (one-size-fits-all) with few a priori exclusions. ${ }^{39}$ Like the Jaffe and Lerner analysis, the NAS Report bases

\footnotetext{
32. Jaffe \& Lerner, supra note 22, at 201-02.

33. Id. at 59-64.

34. See Mark A. Lemley, Rational Ignorance at the Patent Office, 95 Nw. U. L. Rev. 1495 (2001).
}

35. Shuba Ghosh \& Jay Kesan, What Do Patents Purchase? In Search of Optimal Ignorance in the Patent Office, 40 Hous. L. REv. 1219 (2004).

36. Nat'l Research Council, Nat'l Acads. of Sci., A Patent System for the 21 st Century (Stephen A. Merrill, Richard C. Levin \& Mark B. Myers eds., 2004) [hereinafter "NAS Report"].

37. See, e.g., Patents in the Knowledge-Based Economy (Wesley M. Cohen \& Stephen A. Merrill eds., 2003) (one such industry specific study); cf. NAS Report, supra note 36 , at 36 .

38. NAS Report, supra note 36 , at 41 .

39. Id. at $41-44$. The report observed that some doubts about the propriety of software and business method patents existed but considered the matter insufficiently clear to reach any firm conclusions or recommendations. Id. at $44 \mathrm{n}$. 11 . Given the composition of the Committee on Intellectual Property Rights in the Knowledge-Based Economy, which included several corporate and patent professionals, it is not surprising that the group declined to question the dogma that patents should be available for "anything under the sun made by man." Even if this 
this criterion not on systematic research about the optimal promotion of the useful arts but rather on the dubious premises that Congress intended patent law to apply to "anything under the sun made by man" and that such broad availability of a uniform system of patent protection is justified by economic analysis. The report suggests that the problems associated with new subject matter fields, such as business methods, are only transitional. ${ }^{40}$ While this may be partially true for assessing novelty and non-obviousness, the NAS Report overlooks the broader question of whether patent protection is needed at all or whether the default regime of patent law, with its 20 year duration, limited defenses, and strong remedies, is appropriate. Given its "unitary system" criterion, the NAS Report recommends systemic as opposed to categorical reforms.

The Federal Trade Commission's 2003 report, To Promote Innovation: The Proper Balance of Competition and Patent Law and Policy, ${ }^{41}$ comes the closest to considering categorical reforms. Chapter 3 of this study examines the effect of the current patent system on innovation in several important and rapidly evolving industries: pharmaceuticals, biotechnology, semiconductors, and software/Internet. The section of the report discussing the software and Internet industries concluded:

The software and Internet industries generally are characterized by five factors: (1) innovation occurs on a cumulative basis; (2) capital costs are low, particularly relative to the pharmaceutical, biotechnology and hardware industries; (3) the rate of technological change is rapid, and product life cycles are short; (4) alternative means of fostering innovation exist, including copyright protection and open source software; and (5) the industries have experienced a regime change in terms of availability of patent protection.

Panelists consistently stated that competition drives innovation in these industries. Innovation is also fostered by some industry participants' use of copyright protection or open source software. Several panelists discounted the value of patent disclosures, because the disclosure of a software product's underlying source code is not required.

phrase were not taken out of context, however, the NAS was certainly at liberty to propose to Congress that patentable subject matter be circumscribed and/or tailored to reflect technology-specific differences.

40. Id. at 90.

41. Fed. Trade Comm'n, To Promote Innovation: The Proper Balance of ComPetition and Patent Law and Policy (2003) [hereinafter "FTC Report"]. 
Many panelists and participants expressed the view that software and Internet patents are impeding innovation. They stated that such patents are impairing follow-on incentives, increasing entry barriers, creating uncertainty that harms incentives to invest in innovation, and producing patent thickets. Panelists discussed how defensive patenting increases the complexity of patent thickets and forces companies to divert resources from $R \& D$ into obtaining patents. Commentators noted that patent thickets make it more difficult to commercialize new products and raise uncertainty and investment risks. Some panelists also noted that hold-up has become a problem that can result in higher prices being passed along to consumers. ${ }^{42}$

Despite these observations, the report limits its specific recommendations to system-wide recommendations: instituting an improved post-grant opposition system; changing the burden of proof in adjudicating patent validity; tightening the non-obviousness standard; increasing funding of the Patent Office; improving examination procedures; requiring publication of all patent applications after 18 months; creating a prior user right with regard to claims introduced in continuing applications; and increasing the threshold to establish willful infringement. ${ }^{43}$ The FTC declined to recommend that Congress curtail patentable subject matter or make any categorical adjustments to patent standards, stating only that courts should "consider possible harm to competition-along with other possible benefits and costs-before extending the scope of patentable subject matter." ${ }^{, 4}$

Like the Jaffe and Lerner study and the NAS Report, the FTC Report falls back on convention and political expedience rather than economic analysis in declining to confront categorical reforms. The FTC Report does not consider abolition or restriction of patent protection for computer software. With regard to business methods, the Report observes that:

defenders of business method patents stressed that universality of patentable subject matter has been a significant factor in U.S. technological development. They argued that in the absence of clear empirical evidence, the default position should be that an invention is patentable. Stated alternatively, they suggested that

42. Id. ch. 3 , at 55-56.

43. Id. Executive Summary, at 7-17.

44. Id. at 14 . 
the promotion of innovation should be presumed unless empirical evidence to the contrary exists. ${ }^{45}$

The Report then cited presenters who testified that "business methods traditionally evolve in response to competition and internal business needs, without regard to legal rights to exclusivity" and may impair follow-on innovation. ${ }^{46}$ Nonetheless, it declined to make any recommendation for judicial or legislative action to restrict patentability of business methods because of the complexity of the issues and the diversity of views expressed. $^{47}$

These studies indicate that policy analysts have been unable to develop and apply a comprehensive method for analyzing the full range of patent reform options. Constraining patent reform to "one-size-fits-all" options potentially overlooks policies that could enhance innovation and competition. ${ }^{48} \mathrm{~A}$ comprehensive method for evaluating patent reforms promises great social benefit by reducing the tremendous social costs-in terms of process and anti-competitive effects-of the present patent system.

\section{A Comprehensive Framework for Reforming the Patent System}

The present invention integrates both systemic and categorical patent reforms within a cohesive evaluative framework. Systemic patent reforms are defined as reforms that would apply to all fields of patentable subject matter. Categorical reforms are defined as reforms that would either exclude particular classes of "technology" from patent protection or afford different classes of patentable subject matter different requirements or remedies. Use of the comprehensive framework increases the likelihood of achieving optimal incentives for innovation.

Figure 2 presents a flow chart illustrating the invention. The first step is to diagnose the problems of the current patent system. The second step branches into two parallel evaluative processes: (a) identifying and evaluating systemic reform options (such as implementing a post-grant opposition system or changing the presumption of validity); and (b) identifying and evaluating categorical reform options (such as excluding business method patents or altering the duration of software patents). Each evaluative process assesses the expected costs and benefits of these

45. Id. ch. 4 , at 43 .

46. Id.

47. Id.

48. See Michael W. Carroll, One for All: The Problem of Uniformity Cost in Intellectual Property Law, 55 AM. U. L. Rev. 845 (2006). 
reforms and determines the expected net benefits. Step 3 evaluates combined reform options-drawn from the union of both systemic and categorical reform possibilities-and determines the net expected value of such mixed reform strategies. It is possible to go through Steps 2a and $2 \mathrm{~b}$ and find in Step 3 that some reforms identified in Step 2a are not worth pursuing in light of categorical reforms identified in Step 2b. In other words, the combination of these reforms is not simply additive but may be integrative. Suppose, for example, that the Step 2a analysis points in the direction of a much higher standard of nonobviousness as a second best way of mitigating problems associated with a software patent thicket. But if Step $2 b$ leads to a recommendation that software patents be eliminated or curtailed, then raising the nonobviousness standard (across the board) would not necessarily be warranted. Step 4 selects the reform or reforms yielding the highest net expected benefits.

As part of this process, the policy analyst would need to grapple with several complicating issues, such as whether problems in setting and policing boundaries associated with categorical rules would make such policies unworkable. The method could incorporate both the experience of other nations and the experience from earlier periods of the U.S. patent system. For example, the United States barred patents on business methods for much of the 20th century and Europe continues to do so. The United States also barred or substantially limited software patents for many years. It should be noted that boundaries need not be perfect in order for categorical reforms to be worthy of consideration. Many areas of the law face definitional issues. The Supreme Court has previously indicated in the context of software patents that "[t]he concept of patentable subject matter under $\S 101$ is not 'like a nose of wax which may be turned and twisted in any direction ....,",49 The policy analysis might also examine the ability of the system to change over time. Policy reforms might include institutional mechanisms by which patent policy can be reviewed periodically.

One skilled in the art of patent policy analysis would appreciate the great benefit of providing objective and unbiased analysis aimed at pursuing the true goal of the patent system-“"to promote progress in the ... useful arts"- and not putting political expediency and the private interests of particular players above the broader social interest. The invention also avoids the use of biased burdens of proof, such as a presumption that patent protection should be available for all innovations, regardless

49. Parker v. Flook, 437 U.S. 584, 590 (1978) (quoting White v. Dunbar, 119 U.S. 47, 51 (1886)). It would be possible to exclude software reasonably effectively by barring patents on any process or apparatus in which the point of novelty resides in a software element. See Diamond v. Diehr, 450 U.S. 175, 200-02, 219 (1981) (Stevens, J., dissenting). 
of field, unless it can be shown empirically that such protection would be harmful. The costs of the patent system are not always easily measured, and those possessing the best information may enjoy private benefits (such as exclusion of competition) that make them unwilling to reveal such information. ${ }^{50}$

Figure 2

A Method for Reforming the Patent System

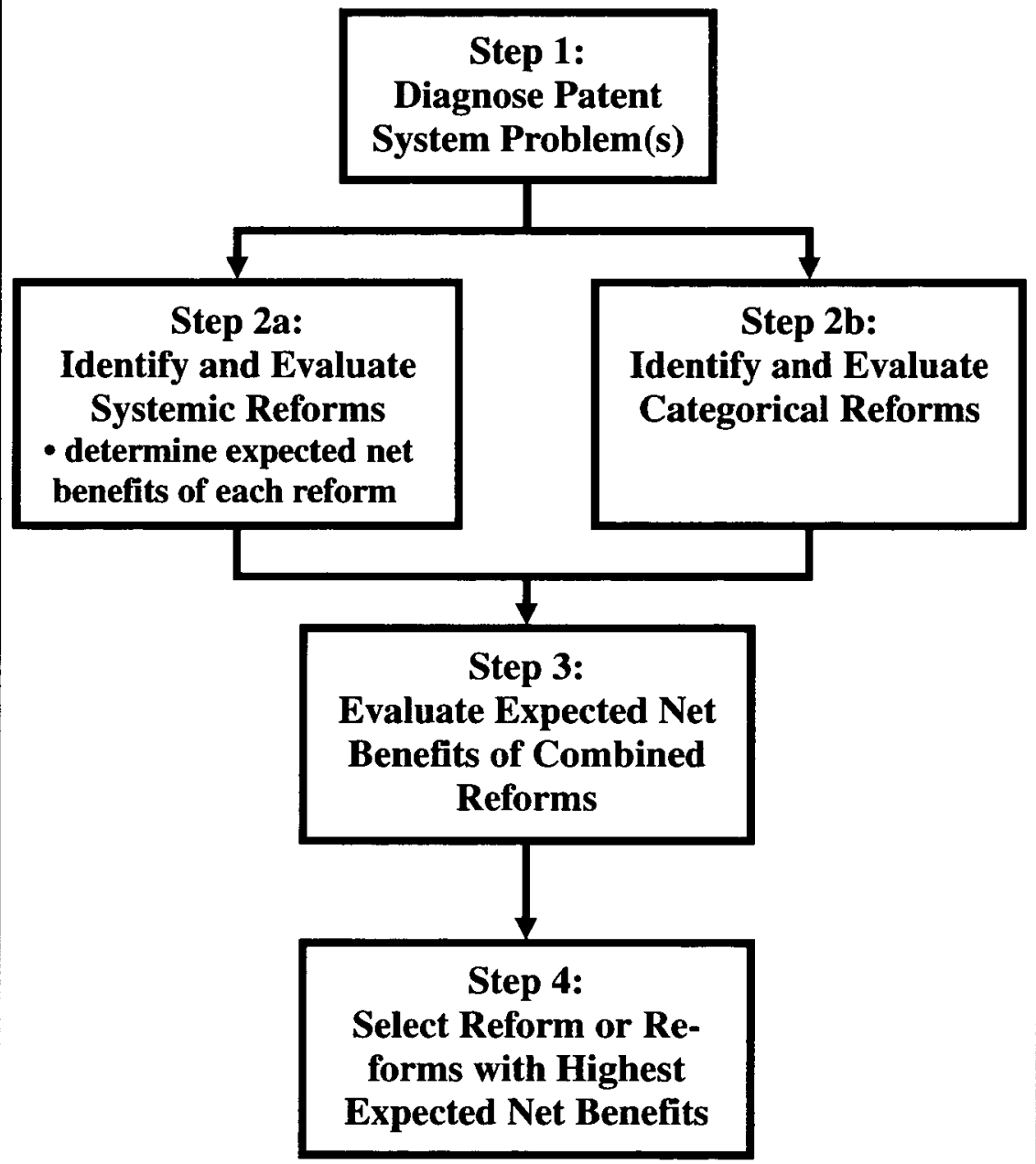

50. See Arnold Plant, The Economic Theory Concerning Patents for Inventions, 1 ECONOMICA (n.s.) 30 (1934). 
Although it might seem that the present invention would be obvious to one skilled in the art of patent policy analysis, there is good reason to believe that it passes muster under the Federal Circuit's standards for judging non-obviousness. ${ }^{\text {s1 }}$ Notwithstanding the fact that each element of the claimed invention is contained in the prior art, the combination of elements has not been published. Similarly, since this is a new patent field, examiners have relatively little training in this area, there is little or no patent prior art, and time and database constraints severely limit the ability of examiners to search non-patent prior art. ${ }^{52}$ Furthermore, the "leading" studies all teach away from the claimed invention. ${ }^{53}$

The Jaffe and Lerner, NAS, and FTC policy analyses are preoccupied with implicit judgments regarding what reforms will not be blocked by interest groups. This concern prevents them from seriously considering a range of categorical patent reforms that could well better "promote progress of the useful arts" than systemic reforms. They fail to recognize the inherent imprecision and costliness of quality control. They also reflect undue optimism that the nonobviousness standard can solve the manifest problems. The nonobviousness problem is inherently difficult and leaves open the possibility of undeserved patents hindering competition. Furthermore, the studies fail to recognize the adverse long-term effects of the creation of patent portfolios in the information technology

51. See In re Sang Su Lee, 277 F.3d 1338, 1343-44 (Fed. Cir. 2002) (requiring documentation of a teaching, suggestion, or motivation to combine references); In re Dembiczak, 175 F.3d 994, 999 (Fed. Cir. 1999) (observing that "the best defense against the subtle but powerful attraction of a hindsight-based obviousness analysis is rigorous application of the requirement for a showing of the teaching or motivation to combine prior art references"); C.R. Bard, Inc. v. M3 Sys., Inc., 157 F.3d 1340, 1352 (Fed. Cir. 1998) (describing "teaching or suggestion or motivation [to combine]" as an "essential evidentiary component of an obviousness holding"); In re Rouffet, 149 F.3d 1350, 1359 (Fed. Cir. 1998) ("the Board must identify specifically ... the reasons one of ordinary skill in the art would have been motivated to select the references and combine them"); In re Fritch, 972 F.2d 1260, 1265 (Fed. Cir. 1992) (examiner can satisfy burden of obviousness in light of combination "only by showing some objective teaching [leading to the combination]"); In re Fine, 837 F.2d 1071, 1075 (Fed. Cir. 1988) (evidence of teaching or suggestion "essential" to avoid hindsight).

52. See FTC Report, supra note 41, Chapter 5, at 4-5 (estimating the average time that an a patent examiner devotes to all aspects of patent examination--including prior art searching, correspondence, analysis, revision, and drafting written responses and disposition--at between 12 and 25 hours per application); See also Robert P. Merges, As Many as Six Impossible Patents Before Breakfast: Property Rights for Business Concepts and Patent System Reform, 14 BERKELEY TECH. L.J. 577 (1999); Mark A. Lemley, Rational lgnorance at the Patent Office, 95 Nw. U. L. REv. 1495 (2001).

53. See Gambro Lundia AB v. Baxter Healthcare Corp., 110 F.3d 1573, 1579 (Fed. Cir. 1997) (concluding that an invention was not obvious in part on the basis of a finding that a reference "did not disclose the use of valves to bypass the dialyzer, but actually taught away from that solution"); In re Braat, No. 90-1197, 1990 WL 143491, at *2 (Fed. Cir. 1990); In re Dow Chem. Co., 837 F.2d 469, 473 (Fed. Cir. 1988); W.L. Gore \& Assocs., Inc. v. Garlock, Inc., 721 F.2d 1540, 1551-53 (Fed. Cir. 1983); Lance L. Barry, Teaching $A$ Way IS NOT Teaching Away, 79 J. Pat. \& Trademark OfF. Soc'y 867 (1997). 
industries. At the same time, they demand both perfection and irrefutable empirical proof for categorical reform. In so doing, they fail to recognize or evaluate the key policy tradeoffs of patent policy: (1) whether patent protection is needed or justified (based a on cost-benefit analysis) in particular fields; and (2) the extent to which boundary problems are so substantial that categorical reform is wholly infeasible. On the latter question, prior U.S. patent law experience, ${ }^{54}$ the previous rule against business method patents, and the evidence from Europe in limiting both software and business method patents suggest that categorical reforms in these areas are feasible. With regard to biotechnology, it would not be difficult to bar composition claims on human genetic code. Whether or not such a policy is worthwhile remains to be seen. But it should not be ignored.

Prospective implementation of categorical reforms neutralizes or reduces the political economy concern. To the extent that those interests that hold patents would stand in the way of salutary categorical patent reforms on the ground that they would lose valuable rights, categorical reforms could be implemented on a prospective basis. In this way, patent owners would obtain a short run benefit of having secured some exclusive rights in markets in which no new patents would be available (or, in the case of tailored categorical reforms, where the value of new patents would be less). Even so, firms in the industry would immediately, upon passage of such legislation, move toward more competitive business strategies and stop their costly patent acquisition efforts. Such an approach could also diffuse the prisoner's dilemma that may be occurring in some marketplaces whereby all or many of the participants would prefer that patents did not inhibit business decision making, but are forced to pursue patent protection in order to avoid being vulnerable to the patents of competitors and be in a position to cross-license. ${ }^{55}$

\section{Preferred Embodiments}

The claimed invention has direct application to the current U.S. patent reform debate. There is good reason to believe that the present patent "crisis" can be traced to a substantial and growing use of patents in the

54. See generally Parker, 437 U.S. 584 (barring patents for inventions in which the point of novelty is software-based).

55. Some have suggested that this pattern characterizes the semiconductor industry. See Rosemarie H. Ziedonis, Patent Litigation in the U.S. Semiconductor Industry, in PATENTS IN THE KNOWLEDGE-BASEd ECONOMY, supra note 37, at 180; Bronwyn H. Hall \& Rosemarie H. Ziedonis, The Patent Paradox: Empirical Study of Patenting in the U.S. Semiconductor Industry: 1979-1995, 32 RAND J. EcoN. 101 (2001); FTC Report, supra note 41, ch. 3, at 23-29, 51-55. 
software industry ${ }^{56}$ as well as the emergence of business method patenting. Since 1980, the number of software patents issued each year in the United States has grown from about $1 \%$ of total patents to approximately $15 \%(24,891$ of 167,438$)$ by $2002 .{ }^{57}$ Between 1984 and 2000 , software patents grew from $3 \%$ of litigated patents to $22 \% .{ }^{58}$ Business method patents are still a relatively small percentage of overall patents, but their potential breadth has caused substantial problems for emerging businesses.

The boundaries of software and business method patents are inherently ambiguous. ${ }^{59}$ Whether or not software patent quality is any worse than in other fields, ${ }^{60}$ there are numerous false positives (patents that should not have issued) that are disrupting businesses and, more importantly, there is relatively little evidence that software patents promote software innovation. ${ }^{61}$ The growing evidence is that most software patenting is driven by strategic considerations (such as building patent portfolios for defensive purposes) and not as support for innovation. ${ }^{62}$ Even software companies that had long opposed software patenting are being compelled to build their own patent arsenal. ${ }^{63}$ Much of the costly

56. See James Bessen \& Robert M. Hunt, An Empirical Look at Software Patents (2004) http://www.researchoninnovation.org/swpat.pdf [hereinafter "Empirical Look at Software Patents"]; Bronwyn H. Hall \& Megan MacGarvie, The Private Value of Software Patents (Sept. 2006) (unpublished manuscript) (finding on the basis of stock market data that there is no evidence that software patents have benefited software firms); Bronwyn H. Hall, Exploring the Patent Explosion, 30 J. Tech. Transfer 35 (2005); Bronwyn H. Hall, Business Method Patents, Innovation, and Policy, (NBER Working Paper No. W 8717, 2003); Robert M. Hunt, You Can Patent That? Are Patents on Computer Programs and Business Methods Good for the New Economy?, Philadelphia Fed. Res. Bank Bus. Rev., Q1 2001, at 5, available at http://www.phil.frb.org/files/br/brq10lbh.pdf.

57. See Empirical Look at Software Patents, supra note 56, at 47.

58. See James Bessen \& Michael Meurer, Do Patents Work? ch. 7 at 8 (2006) (manuscript).

59. Id.

60. See John R. Allison \& Emerson H. Tiller, The Business Method Patent Myth, 18 BERKELEY TECH. L.J. 987 (2003).

61. See Ronald J. Mann \& Thomas W. Sager, Patents, Venture Capital, and Software Startups, REs. POL'y (forthcoming 2007) (reporting that only one in four venture-backed software firms acquired patents, but finding that patent acquisition in these firms is positively correlated with several measures of progress); James Bessen, A Comment on "Do Patents Facilitate Financing in the Software Industry?" (Boston Univ. Sch. of Law Working Paper No. 06-13, May 2005), available at http://www.researchoninnovation.org/comment\%20on\%20 Mann.pdf.

62. See James Bessen, Patent Thickets: Strategic Patenting of Complex Technologies (Working Paper, 2003), http://www.researchoninnovation.org/thicket.pdf; Gideon Parchomovsky \& R. Polk Wagner, Patent Portfolios, 154 U. PA. L. Rev. 1, 46-49 (2005) (describing IBM's efforts to build a vast patent portfolio); An Empirical Look at Software Patents, supra note 56.

63. After many years of opposing software patenting, Oracle Corporation has relented and assembled its own arsenal of over 900 patents. See Official Policy Statement, Oracle Corporation, Patent Policy (Jan. 26-27, 1994) http://pf.ai.mit.edu/Patents/testimony/ 
litigation in the software industry to date has involved smaller players, including non-manufacturing entities, suing established firms. ${ }^{64}$ The recent lawsuit filed by IBM against Amazon.com indicates that the levee holding back even more costly litigation may be breaking, ${ }^{65}$ just as Texas Instruments' foray into the patent litigation arena two decades ago led to the massive buildup of semiconductor patent portfolios. ${ }^{66}$

The costs associated with software and business method patents arise outside of formal litigation as well. Holders of such patents often threaten companies with litigation, resulting in large expenditures for opinion letters to determine exposure (if any) and to reduce the risk of willful infringement if litigation ensues. Opinion letters can cost in excess of $\$ 40,000$ per patent asserted. Start-up companies are easy targets for holders of weak patents of ambiguous scope because of the fragility of their funding and the time-sensitivity of their business plan. The opportunity to cash in on questionable patents has attracted a new breed of company that acquires patents in bankruptcy sales and on the open market for the sole purpose of asserting them against lucrative targets. One such entity, for example, acquired a patent for $\$ 50,000$ that it subsequently asserted against Intel Corporation, seeking $\$ 8$ billion in damages and a permanent injunction. ${ }^{67}$

Thus, in addition to the systemic reforms currently under consideration, the claimed method could be used to explore the full range of categorical reforms. Although ongoing legislative review of patent policy

statements/oracle.statement.html (statement presented at the U.S. Patent and Trademark Office's Software Patent Hearings, San Jose, California).

64. See, e.g., NTP, Inc. v. Research In Motion, Ltd., 2003 WL 23100881 (E.D. Va. 2003), aff'd in part, rev'd in part, and remanded, 418 F.3d 1282 (Fed. Cir 2005), cert. denied 126 S.Ct. 174 (2006); Mercexchange, L.L.C. v. eBay, Inc., 275 F.Supp.2d 695 (E.D. Va. 2003), rev'd in part and affd in part 401 F.3d 1323 (Fed. Cir. 2005), vacated and remanded, 126 S.Ct. 1837 (2006).

65. See Steve Lohr, I.B.M. Sues Amazon.com over Patents, N.Y. Times, Oct. 24, 2006, at C1; See also Anne Broache \& Dawn Kawamoto, Amazon Pays \$40 Million to Settle Patent Dispute, CNET News.com (Aug. 11, 2005), http://news.com.com/Amazon+pays+40+ million+to+settle+patent+dispute/2100-1030_3-5829193.html (settling lawsuits relating to e-commerce patents); Gary L. Reback, Patently Absurd, Forbes, June 24, 2002, at 44 (recounting how IBM was able to extract upwards of $\$ 20$ million from Sun Microsystems for seven patents of questionable validity);

66. See Jaffe and Lerner, supra note 22, at 57-59; Ziedonis, Patent Litigation in the U.S. Semiconductor Industry, supra note 55.

67. See Mathew Ingram, Guarding Ideas or Just Patent Blackmail?, Globe \& MaIL (Canada), June 2, 2005, at B14 (noting that the term "patent troll" was coined to describe TechSearch's suit against Intel after the term "patent extortionist" gave rise to a libel suit); Andrew Zajac, Intel Defamed Patent Rival, Chicago Tribune, Apr. 22, 1999, at Business-1 (describing the libel suit). See also Brenda Sandburg, A Modest Proposal: After Six Years of the Status Quo, Software Companies Urge Congress to Revamp the Patent System, THE RECORDER, May 5, 2005, http://www.law.com/jsp/article.jsp?id=1115370308794 (describing the TechSearch suit within the context of the current legislative reform efforts). 
as technological fields develop would be institutionally challenging, there is good reason to believe that there is sufficient experience with software patents and business method patents today to make a reasonably sound judgment as to the desirability of a moratorium or tailoring of protection for some fields of technology.

While the present invention has been described in terms of various embodiments, it is not intended that the invention be limited to these embodiments. Modification within the spirit of the invention will be apparent to those skilled in the art. For example, policy analysts could improve patent law with respect to business methods, biotechnology, or nanotechnology applying the method taught herein.

\section{Claims}

What is claimed is:

1. A method for reforming the patent system comprising:

diagnosing problems of the existing patent system in promoting progress in the useful arts;

identifying and evaluating the net benefits of non-technology field-specific reforms (systemic reforms);

identifying and evaluating the net benefits of technology field-specific reforms (categorical reforms);

evaluating the net benefits of combined systemic and categorical reforms;

selecting the patent system reform or reforms offering the highest expected net benefits.

2. The method described in Claim 1, wherein the categorical reforms are implemented through legislation that applies only prospectively.

50. The method described in Claim 1, wherein ... 